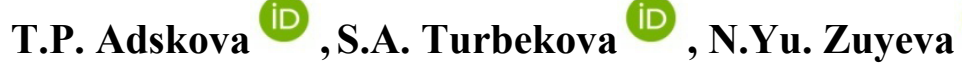 \\ Al-Farabi Kazakh National University, Kazakhstan, Almaty, \\ e-mail: adskova.tp@mail.ru, sturbekova@mail.ru,nataliazueva@rambler.ru
}

\title{
PROJECT ACTIVITIES AT THE LESSONS ON PROFESSIONAL RUSSIAN LANGUAGE
}

In recent years, the activity-based approach to languages teaching has become a subject of particular attention. The purpose of the article is to investigate the activity approach in teaching professional Russian to the bachelor-students of natural sciences. The article proposes a methodology for organizing and conducting students' project activities when teaching professional Russian in order to use a special language in situations as close as possible to professional communication. The goals, objectives and purpose of the course "Professional Russian Language" are being determined. The essence of the concept of "project activity" is revealed from linguodidactic positions, which is based on the use of the language in situations maximum close to the conditions of real communication; with emphasis on independent work of students (individual and team); the selection of topics of great interest to students and directly related to the conditions, under which the project is being implemented; selection of language material, types of tasks, establishing a sequence of work in accordance with the theme and purpose of the project, visual representation of the outcomes. Depending on the dominant type of speech activity, there is given the projects typological groups classification: research, creative, role-playing, informative, project-oriented. Particular attention is paid to the description of the role-playing business project. The analysis shows, that the use of design technologies in teaching professional Russian language contributes into the formation of intellectual, creative and communicative skills.

Key words: professional Russian language, project activity, business-project, business plan, industrial advertising, project technologies.

Т.П. ААскова, С.А. Турбекова, Н.Ю. Зуева,

Әл-Фараби атындағы Қазақ ұлттық университеті, Қазақстан, Алматы қ., e-mail: adskova.tp@mail.ru, sturbekova@mail.ru,nataliazueva@rambler.ru

\section{Кәсіби орыс тілі сабақтарындағы жобалық қызмет}

Соңғы жылдары тілдерді оқытуда белсенділікке негізделген тәсілге ерекше назар аударылуда. Мақаланың мақсаты - жаратылыстану мамандықтарында оқитын бакалаврларын кәсіби орыс тілін оқытудағы белсенділік тәсілін зерттеу. Мақалада кәсіби орыс тілін оқытуда кәсіби қарым-қатынасқа мүмкіндігінше жақын жағдайларда арнайы тілді қолдану мақсатында студенттердің жобалық іс-әрекетін ұйымдастыру және өткізу әдістемесі ұсынылған. «Кәсіби орыс тілі» курсының мақсаты, міндеттері мен мақсаты айқындалады. Аингводидактикалық ұстанымдардан нақты жобалық жағдайға жақын жағдайларда тілді қолдануға негізделген «жобалық іс-әрекет» ұғымының мәні ашылады; студенттердің өзіндік жұмысына (жеке және топтық) назар аударылады; студенттерді қызықтыратын және жоба жүзеге асырылатын жағдайларға тікелей байланысты тақырыптар таңдау; тілдік материалдарды, тапсырмалардың түрлерін таңдау, жобаның тақырыбы мен мақсатына сәйкес жұмыстың ретін құру, нәтижені көрнекі түрде көрсету сияқты мәселелер қарастырылады. Сөйлеу әрекетінің басым түріне байланысты жобалардың типологиялық топтарының жіктелуі берілген: зерттеу, шығармашылық, рөлдік, ақпараттық, жобаға бағытталған. Рөлдік бизнес-жобаны сипаттауға ерекше назар аударылады. Та^дау көрсеткендей кәсіби орыс тілін оқытуда жоба технологияларын қолдану интемлектуалды, шығармашылық және коммуникативтік Аағдыларды қалыптастыруға ықпа^ етеді.

Түйін сөздер: кәсіби орыс тілі, жобалық қызмет, бизнес-жоба, бизнес-жоспар, өндірістік жарнама, жоба технологиялары. 


\title{
Т.П. ААскова, С.А. Турбекова, Н.Ю. Зуева \\ Казахский национа^ьный университет им. аль-Фараби, Казахстан, г. Амматы, e-mail: adskova.tp@mail.ru, sturbekova@mail.ru, nataliazueva@rambler.ru \\ Проектная деятельность на занятиях по профессиональному русскому языку
}

\begin{abstract}
В последние годы деятельностный подход в обучении языкам стал преАметом особого внимания. Цель статьи - исследовать деятельностный подход при обучении профессиональному русскому языку бакалавров естественнонаучных специальностей. В статье предлагается методика организации и проведения проектной деятельности студентов при обучении профессиональному русскому языку с целью использования специального языка в ситуациях, максимально приближенных к профессиональному общению. Определяются цели, задачи и назначение курса «Профессиональный русский язык». С мингводидактических позиций раскрывается сущность концепта «проектная деятельность», в основе которого лежит использование языка в ситуациях, максимально приближенных к условиям реального общения; с акцентом на самостоятельной работе учащихся (индивидуальной и групповой); выборе темы, вызывающей большой интерес для обучаемых и непосредственно связанной с условиями, в которых выполняется проект; отборе языкового материала, видах заданий, установлении последовательности работы в соответствии с темой и целью проекта, наглядном преАставлении результата. В зависимости от Аоминирующего вида речевой деятельности приводится классификация типологических групп проектов: исследовательских, творческих, ролево-игровых, информационных, проектно-ориентированных. Особое внимание уделяется описанию ролево-игрового бизнес-проекта. Анализ показывает, что использование проектных технологий при обучении профессиональному русскому языку способствует формированию интемлектуальных, творческих и коммуникативных умений.

Ключевые слова: профессиональный русский язык, проектная деятельность, бизнес-проект, бизнес-план, промышленная реклама, проектные технологии.
\end{abstract}

\section{Introduction}

Discipline «Professional Russian language» occupies a special place in the system of training bachelor-students of natural sciences. Currently, in the system of higher education, the Russian language teaching, as an important element of general and vocational culture and as a means of professional communication has gained particular relevance. For university students, learning the professional Russian language is not only a means of mastering a future specialty, but also the ability to carry out competent professionally-oriented communication, which will make it easy to adapt to the dynamically changing conditions of vocational activity.

The content of the discipline "Professional Russian Language" is aimed at the formation of linguistic and professional competence, integrating the general cultural, intellectual, social and vocational qualities of a specialist.

The purpose of the course is to form students' skills: proficiency in specialty language, vocational speech; professional communication; knowledge of vocational speech culture; possession of the specialty sublanguage term system; writing and defending educational and scientific works; creating communicative products in compliance with the requirements of the communication situation and professional communication purpose; work with educational, scientific and reference literature in Russian; work with professional terminography.

The purpose of the course is implementing the principle of training vocational orientation, the formation of students' communicative competence, based on the specialty language, necessary for adequate professional communication in the field of the activity, deepening and upgrading the knowledge through self-education and its creative application to practice. "Teaching a specialty through language and teaching a language through a specialty is one of the important problems of vocational training in the non-linguistic university" (Miroshnikova, 2005: 176).

The basis of training is the principle of validity, reasoning, response conclusiveness, which supposes the background assumption at a complete, consistent, evidence-based expression of one's opinion. The starting point for the implementation of this principle is the organization of an academic process, when the student faces the need in justifying own point of view, own solution to the problem, which envisages the inclusion of design tasks, that allow integrate student's knowledge from different fields of science upon solving one or another problem. The project method is the core of developmental learning. 


\section{Experiment}

Dependent on the dominating method in the project or type of speech activity, the following typological groups of projects are distinguished: research, creative, role-playing, informative, project-oriented. When teaching the second language, information projects are most relevant. This type of project is initially aimed at collecting information about any object, phenomenon; familiarization of project participants with this information, its analysis, generalization of facts. Such projects require a well-designed structure. The structure of the information project can be represented as follows: the purpose of the project; subject of information search; information processing methods; information retrieval result. Information projects are often integrated into research projects and become their organic part. Research projects are completely subordinated to the logic of a small-scale study, and they have a specific structure: goal of the project, fundamental question, problematic issues, hypothesis, research progress, outcomes, conclusions, information resources.

Undoubtedly, the effective use of design technologies requires a lot of preparatory work, which is carried out in a holistic system of language training. The following requirements are put forward for the use of the project method: the presence of significant research, creative plan problem, that requires integrated knowledge; practical significance of the expectedoutcomes; independent (individual, team) activity in the classroom and outside it; structuring the content of the project (indicating phased tasks by the roles distribution); the use of research methods (determination of the problem, goals and objectives of the study, hypothesis, suggesting ways to solve it, formalizing the final results, analysis of the data, summing up, correction, conclusions). During the study, you can use the technology of "brainstorming", "round table" presentation.

We have made an attempt to develop a methodology for organizing and carrying out the trainees' project activities in teaching professional Russian in order to use a special language in situations as close as possible to professional communication. Of course, projects, being carried out by students, do not pursue purely research goals, and designers are students studying professional Russian as a second language. Students work with special texts in Russian, a resource-information base is formed to solve professional problems, and skills for presenting information are developed. When working on the project, the following tasks were set: systematization of vocabulary on the proposed topic, the formation of students' vocabulary on the specialty. Students are invited to participate in a role-playing business project. According to the dominant method, this is a practice-oriented project. We made an attempt to develop a methodology for organizing and carrying out project activities of students in teaching professional Russian in order to use a special language in situations maximum close to vocational communication. Of course, projects carried out by students, do not pursue purely research goals, the designers are students studying professional Russian as a second language. Students work with special texts in Russian, and there is formed the resource-information base for solving the vocational problems, and developed skills for presenting information. When working on the project, the following tasks were set: systematization of vocabulary on the proposed topic, the formation of students' vocabulary on the specialty. Students are invited to participate in a roleplaying business project. According to the dominant method, it is a practice-oriented project. In terms of participants' number, it is a group project, in terms of duration - a project of medium duration. (Polat, 2008: 272). The phased tasks of preparing a group project were outlined: to think over and discuss ideas for a business project, to distribute roles; select material and draw up a working business plan; prepare an introduction to a business project; write the main part of the speech; prepare the final part of the business project; prepare a persuasive speech in order to obtain a loan for the business project (products); to compose a text of industrial advertising for apparatus (product, device)promotion to the market; prepare a presentation of the business plan; submit a business project.

When preparing a business plan, it is necessary to determine the scope of activities, formulate the main goals, ways to achieve them, make economic calculations of costs, expenses and incomes, indicate the financial position of the company and potential investors. When drawing up a business plan, you should adhere to the following structure: resume, basic idea, organization conditions, description of goods, services or ideas, information about the market, base of potential consumers, information about competing firms, marketing and its goals, production of goods, distribution of responsibilities. Make a convincing presentation, highlight aspects, that might be of interest to investors, and consider the issues. Evaluation criteria during the presentation are: phrase construction, courtesy, timbre and tone of voice, respect for others viewpoints, calmness, appearance, business qualities, posture. moderate gestures, absence of repeated words, speech 
with elements of moderate emotionality, affirmative form.

Students have selected project topics, related to their future specialty: "IBM Watson Artificial Intelligence", "Wi-Charge Wireless Laser Charging", "Robot-toy for children with disabilities", "Virtual Glasses", "Swiss S3 Orbiting Spacecraft", etc. Each project was accompanied by industrial advertising. While creating advertising texts, students used in practice the knowledge, gained during studying the topic "Types of scientific and technical texts". The task of advertising is to attract consumer attention, arouse interest in the advertised product, give arguments in its favor, encourage the consumer to decide to purchase the advertised product. Industrial advertising is more complex, than consumer goods advertising. It requires solid arguments. In such advertising, the effect at emotions has practically no effect. Rational arguments can be very different: examples from the history of the technology development, evidence of specialists, comparison with other products, opinions of specialists, etc. Industrial advertising should contain detailed information about the advantages and properties of the product, a description of the possible areas of application of the product or service, clear illustrations that carry useful information (photographs or diagrams), warranty conditions, etc. (Nazaykin, 2003: 206-209). The text of the advertising publication must reflect a number of particulars. This is the full name of the product, purpose, scope of application, overall and installation dimensions, quality, accuracy and economic benefits, a guarantee of the life or quality, maintenance and repair procedures, technical specifications, set up completeness. Texts of industrial advertising are not only marketing, but also informative. Hence are the unequal linguistic features of this unusual genre of scientific prose: On the one hand, it is accuracy and high terminologization, the use of words in their specific objective logical meanings, impersonality of a statement, strict consistency, completeness, certainty, presentation linearity, the statement narrative nature, the absence of modal-evaluation forms, widespread use of illustrated and graphic language (drawings, graphs, charts, photographs, trademarks and company marks, quality marks, marks of international exhibitions, etc.), indentation strict division upon transferring product characteristics. Also, it is clarity, concreteness and simplicity of presentation, using the method of comparison, "advertising reason" or "slogan". For example, the beginnings of industrial advertising for a mobile application "What is IBM Watson? From the name it's clear, that this is some kind of product of our IBM company. Yes, really ... IBM Watson is an artificial intellect. "We have created a mobile application, that demonstrates the capabilities of IBM Watson and allows us use its artificial intellect!" The text of industrial advertising reflects the characteristics of the product. So, the Wi-Change wireless laser charging is being advertised. Hereby, we indicate technical specifications:

\begin{tabular}{|c|c|}
\hline $\begin{array}{c}\text { Number of chargeable } \\
\text { devices }\end{array}$ & $1-50$ (depends on usage) \\
\hline Energy total flow & $500 \mathrm{~mW}$ \\
\hline Range of vision & $100 \mathrm{o} / 100 \mathrm{~m}$ \\
\hline $\begin{array}{c}\text { Transmission maximum } \\
\text { distance }\end{array}$ & $5 \mathrm{~B}$ \\
\hline Output voltage & $\begin{array}{c}\text { Transmitter 137 137 59 mm } \\
\text { Receiver 10 10 6 9depends } \\
\text { on receipt distance) }\end{array}$ \\
\hline Device dimensions & Built-in power storage \\
\hline Option &
\end{tabular}

In the course of working on the project, presentation of the project there mastered the skills of monolog and dialogue professional speech commands. A dialogue in the form of a scientific discussion is the most complicated. The requirements to conducting a discussion allow, although not immediately, form a vocational speech culture, for example, listen to the interlocutor to the end without interrupting, ask him questions, refute his/her opinions or, on the contrary, agree with him/ her, developing thought. (Kopylova 2003: 185p.).

The criteria for evaluating the outcomes of project activities are: the ability to use various sources of information, the ability to work in collaboration; relevance and significance of the topic; topic complete opening up; ability to set a goal; draw up and implement a plan; conduct reflection; match purpose and action. When evaluating a project presentation, the following criteria are put forward: adequacy to the topic; consistency, presentation logic; a variety of grammatical constructions and vocabulary; compliance with the speech scientific style: use of visual aids, technical means; originality of the proposed solutions; quality performance of the product; answers on questions.

Participation in the project was very useful for students, as it allowed them get really involved into future vocational activities and get an idea, what aspects of the specialty language will be in demand. 


\section{Outcomes and discussion}

The application of design technologies is not new. The project method is based on the ideas of the American philosophers Dewey, Lai, Thorndike, that education is a process of accumulating and reconstructing existing experience in order to deepen its content. John Dewey, the author of a scientific school and pragmatic pedagogy, considered, that everything important, learned and experienced from specific situations, from specially organized experience is from "doing". (Tomyuk, 2011:p.p.2834) "Learning through doing" is the organization of students' independent activities to solve problems, that of interest to them. Such activity organization means shall be, in particular, the project method. As it is denoted in contemporary pedagogy, the design method is an «ideal» cogitative activity and the activity on the conception implementation. (Romanovskaya M. B.,2006:160). A teacher shall motivate the trainees to create the educational environment, specify skills and abilities, organize individual and team work, render an advisory opinion. (Akopyan M. A., Hovhannisyan E. A., Danczuk M, 2015: p.p. 91-100)

The projects, supposed for language learning, possess both general features for all projects, and distinctive peculiarities, amongst which, the main ones are the following: use of the language in situations maximum close to the conditions of real communication; emphasis on independent work of students (individual and team); the choice of topics of great interest to students and directly related to the conditions, in which the project is being implemented; selection of language material, types of tasks and work sequence in accordance with the theme and purpose of the project; visual representation of the result. "Science and engineering achievements all over the world are really impressive and teachers' efforts are directed particularly at that, an academic process is subordinated to the same task». (Shchegol V. I.,2012; p.p.336-339) Design method is the essence of developmental education. Project culture learning promotes the development of conative, communicative, cognitive components. (Dvoretsky, S. F., 2003.:78). Design technology supposes the complex of research, search problems and other methods, creative in the sum and substance. (Lazarev, V. S., 2011:3-11)

The project method is the essence of developmental learning. The project is based on an urgent problem. To solve it, students need not only knowledge of the language, but also possession of certain relevant, creative and communicative skills. In the formation of intellectual skills, the emphasis is on working with information, with a text: determine the main idea, highlight the semantic parts, the main and additional information, draw conclusions, give reasons for theses, using illustrative materials. Creative skills include the ability to generate ideas, which require knowledge in different areas, the ability to find not one, but several solutions to a problem, the ability to predict the solution consequences. Communicative skills include, first of all, the ability to conduct a discussion, listen to and hear the interlocutor, to defend one's point of view, the ability to find a compromise with an interlocutor, the ability to express one's thoughts concisely. The use of design technologies allows you turn the lesson into a discussion, research club, which addresses interesting, practical, significant and accessible problems to the trainees.

\section{Conclusion}

Thus, a learner-centered approach to teaching a second language allows you maintain individuality, learn to use the second language as a means of understanding the world. A prerequisite for the effective implementation of these technologies is to rely on the principle of collaboration, business partnership between a student and a teacher, development of a creative, evolutive speech environment, in which not only informative memory is developed, but also the creative memory, which is not only a reflection of the ability level, intellectual and emotional development, that makes up the inner spiritual life, but also forms a personality.

\section{Литература}

Мирошникова, О.Х. Формирование профессионально-языковых компетенций студентов-физиков: учебнометодический комплекс. - Ростов-на-Дону: Изд-во «Эверест», 2008. - 176 с.

Полат Е.С., Бухаркина М.Ю., Моисеев М.В., Петрова А.Е. Новые педагогические и информационные технологии в системе образования. - М.: Академия, 2005. -272 с.

Назайкин А. Практика рекламного текста. - М.: Боратор-пресс, 2003. - С. 206-209.

Копылова В.В. Методика проектной работы на уроках английского языка. - М.: Дрофа, 2003. - 185 с. 
Томюк О.Н. Концепции опыта в инструментализме Джона Дьюи // Эпистемы: сборник научных статей. - Екатеринбург: Издательский дом «Ажур», 2011. - Вып. 6. - С. 28-34.

Романовская М.Б. Метод проектов в учебном процессе: Методическое пособие. - М.: Центр «Педагогический поиск», 2006. $-160 \mathrm{c}$.

Акопян М.А., Оганнисян Е.А., Данчук М.П. Роль проектной деятельности в личностно ориентированном образовании студентов высшего учебного заведения. // Известия Южного федерального университета. Педагогические науки. - 2015. № 3. - С. 91-100.

Щеголь В. И. Педагогическое образование: Стратегические направления XX1 Века / В. И. Щеголь // Вектор науки ТГУ. Серия: Педагогика, психология. - 2012. - № 4 (11). - С. 336-339.

Дворецкий, С. Формирование проектной культуры / С. Дворецкий // Высшее образование в России. - 2003. - № 4. - 193 c. - C. 78 .

Лазарев, В. С. Новое понимание метода проектов в образовании / В. С. Лазарев // Педагогика. - 2011. -- № 10. - С. 3-11.

\section{References}

Akopyan M. A., Hovhannisyan E. A., Danczuk M. P. (2015) The Role of project activity in the personal-oriented education of students of higher education institutions. Proceedings of the southern Federal University. Pedagogical science. \# 3. P.p. 91-100. (in Russian)

Dvoretsky, S. (2003) Formation of project culture. S. Dvoretsky. Higher education in Russia. \# 4. 193. P. 78. (in Russian)

Kopylova V.V. (2003) Methodology of design work at English lessons. Moscow: Drofa, 185 p. (in Russian)

Lazarev, V. S. (2011) New understanding of the project method in education. V. S. Lazarev. Pedagogy. No10. Pp. 3-11. (in Russian)

Miroshnikova O. H. (2008) Formation of applied language competences of students - physisists. Academic and methodological complex. Rostov-na-Donu: Everest, 176 p. (In Russian)

NazaykinA. (2003) Practice of promotional text. Moscow: Borator press, pp.206-209. (in Russian)

Polat E.S., Bukharkina M.Y., Moiseyev M.V., Petrova A.E. (2005) New pedagogical and information technologies in educational service. Moscow: Akademiya, 272 p. (in Russian)

Romanovskaya M. B. (2006) Project methods in the academic process. Study guide. M.: center «Pedagogical search». 160 p. (in Russian)

Shchegol V. I. (2012) Pedagogical education: Strategic guidelines of the XX1 Century. V. I. Shchegol. Vector of science of TSU. Series: Pedagogy, psychology. No. 4 (11). Pp. 336-339. (in Russian)

Tomyuk O.N. (2011) Conceptions of experience in John Daui's instrumentalism. Episthemes: Collection of scholarly articles. Volume 6, Ekaterinburg: Azhur, pp. 28-34. (in Russian) 